\title{
Responsiveness of Volatility Analysis of the Jakarta Islamic Index on Macroeconomic Variables
}

\author{
Eni Susanti ${ }^{1}$, Ratno Agriyanto ${ }^{2}$, Musahadi $^{3}$, Saifudin Zuhri ${ }^{4}$ \\ Universitas Islam Negeri (UIN) Walisongo, Semarang, Indonesia $a^{1,2,3}$ \\ Institut Agama Islam Negeri (IAIN) Salatiga, Salatiga, Indonesia ${ }^{4}$
}

Submitted: 15 September, 2020; Accepted: 24 July, 2021; Published: 29 July, 2021

\begin{abstract}
This study aims to analyze the influence and response of the Jakarta Islamic Index (JII) volatility to changes in macroeconomic variables. VECM was used to examine the long-and short-term effects, while IRF was used to analyze the JII response. Data were obtained from BPS, BI, and Yahoo Finance monthly from 2015-2020 using global macroeconomic fiscal variables, including inflation, BI and Exchange Rates, Industrial Production Index, World Oil Price, Malaysia Hijrah Shariah Index, and DJIM Malaysia Titan 25 Index. The results show that JII is influenced by inflation variables, BI rate, IPI, OP, MHS, and DJIM in the long term but not the exchange rate. Furthermore, it is influenced by BI rate, IPI, OP, MHS, and DJIM in the short term, while the exchange rate and inflation have no significant effect. Macroeconomic variable shock influence JII by 52,27\% while the rest is influenced by other variables outside the model. This research implies that the JII index is very sensitive to economic changes.
\end{abstract}

Keywords: macroeconomic variables, VECM, IRF, JII Index. 


\section{INTRODUCTION}

The capital market is essential for the economic development of a country as an intermediary for parties with deficits and surplus funds. The volatility of the capital market is sensitive to macroeconomics change. Moreover, the capital market provides access to profit for investors who needs to carefully analyze investment to avoid losses. It also facilitates access to capital injection for company development. Stock is one of the capital market products in Indonesia, a country with sharia and conventional stock systems. The Islamic stock index is an alternative for investors who want to invest in the halal sector. Islamic Sharia guides economic activity in worship, ethics, and morals (Agriyanto, 2015). According to Shanmugam and Zahari (2009), Islamic investing must avoid riba, gharar, maysir, and haram principles.

Investor choice in Islamic indices can be placed on the Indonesian Sharia Stock Index (ISSI) and the Jakarta Islamic Index (JII) (Pantas, 2017). However, JII is more bonafide than ISSI because it accommodates 30 of the most liquid Islamic stock issuers and has developed with a positive trend(Ardana, 2016). Table 1 shows the average capitalization data from JII:

Table 1. JII Capitalization

\begin{tabular}{ccc}
\hline Period & Volume & JII \\
\hline 2015 & $10,402,022.591$ & 645.20 \\
2016 & $11,170,077.233$ & 686.14 \\
2017 & $12,365,740.308$ & 729.72 \\
2018 & $12,972,439.758$ & 688.81 \\
2019 & $12,028,771.083$ & 691.19 \\
2020 & $762,420,000$ & 188,30 \\
\hline
\end{tabular}

Source: Yahoo Finance (accessed 2021, January 21st).

Tabel 1 shows that JII has developed positively, even as its prices decreased between 2017 and 2018. Also, the volume and prices dropped to Rp. 188,30 in 2020 due to the pandemic effect.

The Efficient Market Hypothesis (EMH), also called the random walk proposed by Fama (1970), states that stock prices are influenced by the value information of the company. Information that affects stock price movements could be divided into three forms. The first is the weak form in which the previous price influences the current share price. Second, the semistrong form in which the stock price is influenced by the fundamental company and macroeconomic information. Third, the strong form in which the share price is influenced by the role of the insider company.

Blanchard (2006) stated that certain factors affect stock prices, including the global stock index, exchange rates, and macro conditions. Furthermore, as an Islamic stock index in 
Indonesia, JII is influenced by macroeconomic factors and the global stock index. The stock price index is the value of each share traded in the capital market. It is determined by the transaction actors in the market based on supply and demand(Hartono, 2010).

Hussin, Muhammad, Abu, and Awang (2012) used production index variables, inflation, money demand, and interest and exchange rates on KLSI in Malaysia. The results showed that all variables significantly affect KLSI except interest rates. Furthermore, A1Majali and Al-Assaf (2014) analyzed the long- and short-term effects of GDP, inflation, credit figures, interest rates, savings, and the crisis on stock prices in Jordan. The findings showed that all variables significantly affect stock prices except crisis. Similarly, Pratama (2012) analyzed the effect of M2, the exchange, and SBI interest rates on the JII stock price. The results showed that all variables influence JII. Chun, Arsad, and Huen (2015) analyzed the effect of the production index, M2, exchange rate, and government bonds on KLSI's share price in Malaysia. The results showed that the production index negatively impacts KLSI, while M2, exchange rate, and government bonds have a positive effect. These findings are in line with this study. Based on the theory and previous research, this study decided on inflation, BI and exchange rates, production index, oil prices, and Islamic indices.

Inflation (INF) is an increase in prices over a certain period (Rozalinda, 2015) and measures economic deterioration. Habiburrahman (2015) used multiplier regression to show that inflation negatively affects stock price. Similarly, Harsono and Worokinasih (2018) showed that inflation negatively impacts stock prices using multiple linear regression. In contrast, Simbolon and Purwanto (2018) stated that inflation positively influences stock prices using multiple linear regression.

The Bank Indonesia interest rate (BI rate) is specified by the central bank as a monetary policy stance. Lubis (2017) used VECM and found that stocks are negatively affected by interest rates. Furthermore, Hussin et al. (2012) used VAR and found that interest rates negatively affect stock prices. However, Nurlina (2017) used multiple linear regression and found that interest rates positively and significantly affect stock prices.

The exchange rate is a country's currency compared to other countries (Sakti \& Harun, 2013). It is often used to measure a country's economy. Pantas (2017) used VECM and found that the exchange rate negatively affects stock prices. On the contrary, Andriana (2015) used linear regression and found that the exchange rate positively affects stock prices.

The Industrial Production Index (IPI) is a macroeconomic indicator in which an industry's production output is engaged in manufacturing (Putri, 2018). The manufacturing industry is the largest contributor to national economic development. Hussin et al. (2012) used VAR to examine the effect of IPI on stock prices. The results showed that IPI significantly and 
positively affects stock prices used. However, Chun et al. (2015) used VECM and found that IPI significantly and negatively affects stock prices.

The world Oil Price (OP) is the global oil spot market price based on the type of West Texas Intermediate oil. Fluctuations in world oil prices greatly affect the capital market, which is in line with Rusbariand, Masodah, Riskayanto, and Herawati (2012). The studies used multiple linear regression and found that world oil prices positively affect stock prices. Also, Faraga, Chabachib, and Muharam (2012) used VECM and found that oil prices positively impact stock prices. However, Kelikume and Muritala (2019) used ordinary least squares and found that world oil prices negatively affect stock prices. This supports Alfuadi (2019) which used ordinary least squares and found that oil prices negatively impact stock prices.

Dow Jones Islamic Market Malaysia Titan 25 (DJIM) is a subsidiary of S\&P Dow Jones Indices in Malaysia. Also, it is based on sharia, meaning it is strictly screened by Shariah Advisory Council (SAC). Using multiple linear regression, Kurniawan, Alia, and Apriyani (2019) state that DJIM positively affects stock prices. On the contrary, Febrina, Sumiati, and Rahmawati (2018) used VAR and found that the foreign stock index negatively impacts stock prices.

Malaysia Hijrah Shariah (MHS) is an index of Islamic stocks in Malaysia that strictly screens issuers from the Shariah Advisory Council (SAC) (Shofiyullah, 2014). Wulandari, Herlina, and Chendrawan (2019) used VECM and found that the foreign stock price index negatively affects the stock price index. However, Jayanti, Darminto, and Sudjana (2014) used multiple linear regression and showed that foreign stock prices positively affect stock prices.

This research discusses the macroeconomic effect on stock prices and analyzes the gaps in the previous studies. Also, it adds DJIM and MHS as the variables affecting JII stock price. Malaysia and Indonesia have dominant Muslim domestic populations. The 2010 BPS population census showed that $87.18 \%$ of the Indonesian and $61.3 \%$ of the Malaysian population are Muslims. Furthermore, Putri (2018); Antonio, Hafidhoh, and Fauzi (2013); also Shofiyullah (2014) compared Indonesian and Malaysian Islamic Stocks. Therefore, this study examines the effect of the Indonesian and Malaysian Islamic Stocks. MHS and DJIM are both Islamic indices in Malaysia. Also, the theory of contagion effect, which states that a country's economy affects other countries, allows it to occur on the stock market (Fitriany, 2012). This research is expected to be a reference for stock market players, the government, and academia in policymaking. The research framework is as follows: 


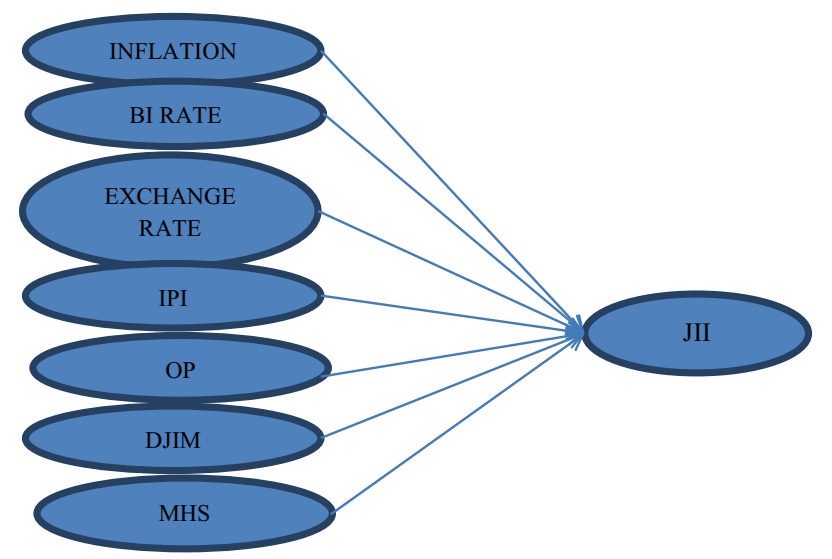

Figure 1. Theoretical Framework

Based on figure 1, this study analyzes the impact of inflation, BI and exchange rates, Industrial Production Index, Oil Prices, Dow Jones Islamic Market Malaysia Titan 25, and Malaysia Hijrah Shariah Index on Jakarta Islamic Index.

\section{METHOD}

This quantitative research used secondary data from the Indonesia Stock Exchange (IDX), Central Bureau of Statistics (BPS), Bank Indonesia (BI), and Yahoo Finance from February 2016 to January 2020. The volatile share prices could be used as Vector Error Correction Model (VECM) for analysis. VECM analysis synchronizes economic behavior in the short run through long-term variables (Gujarati \& Porter, 2012). Stock price analysis is important to compound investment. Impulse Response Function (IRF) analysis is used to observe the response of endogenous variables given by exogenous variables.

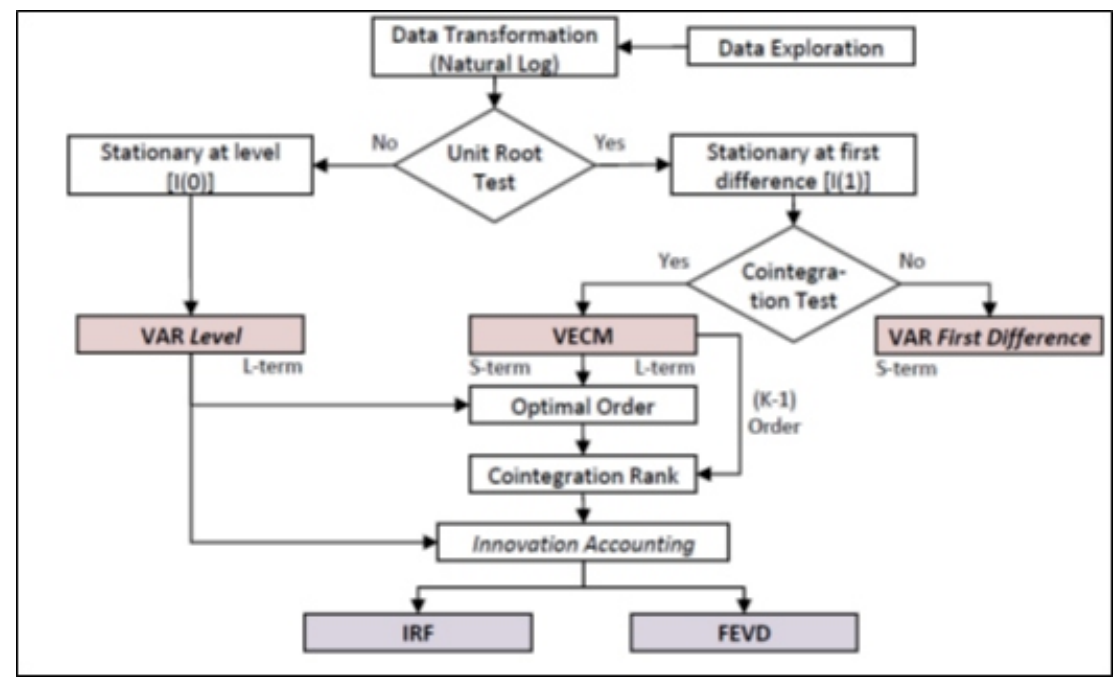

Source: (Basuki and Prawoto, 2017)

Figure 2. VECM Plot 
The first step was performing the stationary test. Widarjono (2005) stated that the data is stationary when the variance is constant over time, and the covariance depends on the lag of the two periods. Second, the lag test is optimal because every economic policy cannot have an effect at that time. Therefore, the optimal lag should be determined because the exogenous variable used is the endogenous variable lag (Akbar, Rusgiyono, \& Tarno, 2016). Third, cointegration testing was performed to determine whether the model has a long-term relationship. It is a requirement for the VECM test, which analyzes the research model's long- and short-term effects. Furthermore, IRF testing is needed to observe the response of each impulse or policy change from exogenous variables. The Eviews 8 application was used in this analysis.

\section{RESULT AND DISCUSSION}

\section{Descriptive Statistic}

This study used JII stock prices as an endogenous variable and inflation, BI and exchange rates, IPI, OP, DJIM, and MHS as exogenous variables. Also, descriptive statistics were used to show the data characteristics in Table 2.

Table 2. Descriptive Statistics

\begin{tabular}{lcccccccc}
\hline & JII & INF & BIRATE & KURS & IP & OP & DJIM & MHS \\
\hline Mean & 685.9945 & 3.740893 & 6.044643 & 13786.11 & 138.6277 & 3.879464 & 1.074629 & 13754.98 \\
Maximum & 787.1200 & 7.260000 & 7.500000 & 15273.10 & 158.0000 & 9.640000 & 1.174000 & 15057.57 \\
Minimum & 556.0900 & 2.480000 & 4.250000 & 13003.00 & 122.2100 & 1.450000 & 1.010900 & 12787.40 \\
Std. Dev. & 49.34702 & 1.129258 & 1.315214 & 509.1476 & 8.832516 & 1.838961 & 0.042020 & 544.7188 \\
Observations & 56 & 56 & 56 & 56 & 56 & 56 & 56 & 56 \\
\hline
\end{tabular}

Table 2 shows the descriptive statistics indicating mean, maximum, minimum, standard deviation, and observation data study. The data were sourced BPS for Industrial Production Index, Inflation, and BI rate. Other data were sourced from Yahoo Finance for DJIM, MHS, Oil Price, and Bursa Efek Indonesia for JII stock prices.

\section{Stationary Test}

The stationary test on time series data is a prerequisite for conducting the cointegration test. The unit root test using the Augmented Dickey-Fuller Test (ADF) method was used to determine the stationary data. The data is said to be stationary when the probability in the ADF test method is less than $5 \%$. 
Table 3. Stationary Test

\begin{tabular}{lllll}
\hline \multirow{2}{*}{ Variables } & Level & & 1 st Difference & \\
\cline { 2 - 5 } & Probability & Information & Probability & Information \\
\hline JII & 0.3611 & Non-Stationary & $0,0000^{* * *}$ & Stationary \\
INFLA TION & $0,0221^{* *}$ & Stationary & $0,0000^{* * *}$ & Stationary \\
BI RATE & 0,7425 & Non-Stationary & $0,0000^{* * *}$ & Stationary \\
KURS & 0.1586 & Non-Stationary & $0,0000^{* * *}$ & Stationary \\
IPI & 0,4694 & Non-Stationary & $0,0000^{* * *}$ & Stationary \\
OP & 0,2563 & Non-Stationary & $0,0000^{* * *}$ & Stationary \\
DJIM & $0,0535^{*}$ & Stationary & $0,0000^{* * *}$ & Stationary \\
MHS & 0,1249 & Non-Stationary & $0,0000^{* * *}$ & Stationary
\end{tabular}

*stationary at $10 \%, * *$ stationary at $5 \%, * * *$ stationary at $1 \%$

Table 3 shows the output in which only inflation is stationary at $1 \%, 5 \%, 10 \%$, showing an increasing trend. Variables in order one are rejected in the VAR and needs to be at a stationary level. Therefore, the autoregressive vector requires a stationary level and an Error Correction Model called VECM(Pantas, 2017).

\section{Lag Optimal Test}

The optimal lag test is important in the VAR testing because the endogenous variable lag is an exogenous variable (Enders, 2004). Determination of optimal lag could avoid serial correlation that results in data, not BLUE (Pratama, 2012). The optimal lag length could be determined using the values of Akaike Information Criteria (AIC) and Schwartz Information Criterion(SIC).

Table 4. Lag Optimal Test

\begin{tabular}{ccc}
\hline Lag & AIC & SIC \\
\hline 1 & 44.38050 & $46.80475^{*}$ \\
2 & 44.52148 & 49.36998 \\
3 & 44.21825 & 51.49101 \\
4 & $41.83202^{*}$ & 51.52902 \\
\hline
\end{tabular}

Table 4 shows that the smallest AIC and SIC values are in the fourth and first lags, respectively. This shows that the best model produced in the VECM test is the lag length 1 and 4.

\section{Granger Causality Test}

Granger causality test was performed to determine whether the variables have reciprocal or causality relationship. The variables have a causality relationship when they have a significant effect or a probability score less than 0.05 . In this test, all variables could be exogenous or endogenous(Basuki \& Prawoto, 2017). 
Table 5. Granger Causality Test

\begin{tabular}{lccc}
\hline Null Hypothesis: & Obs & F-Statistic & Prob. \\
\hline DJIM does not Granger Cause JII & 54 & 1.65680 & 0.2013 \\
JII does not Granger Cause DJIM & & 0.16300 & 0.8500 \\
\hline MHS does not Granger Cause JII & 54 & 0.19834 & 0.8207 \\
JII does not Granger Cause MHS & & 0.58946 & 0.5585 \\
\hline IP does not Granger Cause JII & 54 & 0.00472 & 0.9953 \\
JII does not Granger Cause IP & & 0.18178 & 0.8343 \\
\hline OP does not Granger Cause JII & 54 & 1.86566 & 0.1656 \\
JII does not Granger Cause OP & & 2.04517 & 0.1403 \\
\hline INF does not Granger Cause JII & 54 & 1.91964 & 0.1575 \\
JII does not Granger Cause INF & & 0.77385 & 0.4668 \\
\hline BIRATE does not Granger Cause JII & 54 & 1.77131 & 0.1808 \\
JII does not Granger Cause BIRATE & & 1.32061 & 0.2763 \\
\hline KURS does not Granger Cause JII & 54 & 0.05869 & 0.9431 \\
JII does not Granger Cause KURS & & 1.72698 & 0.1885 \\
\hline
\end{tabular}

Table 5 shows no variable with a significant effect or causality relationship in the research model. This is indicated by the probability score of more than 0.05 or $5 \%$.

\section{Cointegration Test}

The co-integration test was performed to determine whether the research model has long-term co-integration using the Johansen-Test method. The presence or absence of cointegration is seen from the probability value below $5 \%$.

Table 6. Cointegration Test

\begin{tabular}{ccccc}
\hline $\begin{array}{c}\text { Hypothesized } \\
\text { No. of CE(s) }\end{array}$ & Eigenvalue & $\begin{array}{c}\text { Max-Eigen } \\
\text { Statistic }\end{array}$ & $\begin{array}{c}0.05 \\
\text { Critical Value }\end{array}$ & \\
\hline None & & & & \\
At most, $1 *$ & 0.930984 & 136.3443 & 56.70519 & 0.0000 \\
At most, $2 *$ & 0.834607 & 91.77091 & 50.59985 & 0.0000 \\
At most, 3* & 0.619371 & 49.26246 & 44.49720 & 0.0141 \\
At most, 4 & 0.611695 & 48.24413 & 38.33101 & 0.0027 \\
At most 5 & 0.515452 & 36.95152 & 32.11832 & 0.0118 \\
At most 6 & 0.391805 & 25.36022 & 25.82321 & 0.0575 \\
At most, 7 * & 0.299711 & 18.16938 & 19.38704 & 0.0744 \\
\hline
\end{tabular}

* Probability $<5 \%$

Table 6 shows five co-integration relationships in the research model. An asterisk mark indicates a probability value below the $5 \%$ level, and the eigenvalues statistic is greater than the critical value. These results are sufficient to continue testing to fulfill the VECM test. 


\section{VECM Estimation}

The VECM test is useful for analyzing how exogenous variables affect endogenous variables in the long and short term. The effect of exogenous on endogenous variables is determined by comparing the $\mathrm{t}$-statistic and t-table values. In this case, the t-statistic value has a significant effect when it is greater than the t-table value. This research model has 56 observations, and the t-table values at the 5\% and $10 \%$ levels are 1.67722 and 1.29944 , respectively.

Table 7. VECM Test

\begin{tabular}{|c|c|c|}
\hline Variables & Coefficient & T-Statistic \\
\hline \multicolumn{3}{|c|}{ Long Term } \\
\hline INF(-1) & 8.227363 & $2.81257 * * *$ \\
\hline BIRATE(1) & 19.81249 & $7.41332 * * *$ \\
\hline KURS(-1) & 0.316400 & 1.19197 \\
\hline IPI(-1) & -3.610124 & $-3.95744 * * *$ \\
\hline OP(-1) & -8.854995 & $-3.46294 * * *$ \\
\hline $\operatorname{MHS}(-1)$ & -0.038572 & $-4.99412 * * *$ \\
\hline DJIM(-1) & 980.9378 & $8.55188 * * *$ \\
\hline \multicolumn{3}{|c|}{ Short Term } \\
\hline Coint Eq. & -0.654982 & $-4.49423 * * *$ \\
\hline $\mathrm{D}(\mathrm{JII}(-1))$ & 0.461240 & $2.61403 * * *$ \\
\hline D(JII (-2)) & 0.485712 & $2.62976 * * *$ \\
\hline $\mathrm{D}(\mathrm{INF}(-1))$ & -0.249884 & -0.03348 \\
\hline $\mathrm{D}(\mathrm{INF}(-2))$ & -6.634027 & -0.84624 \\
\hline D(BIRATE-(1)) & -2.572919 & -0.23491 \\
\hline D(BIRATE-(2)) & 15.61006 & $1.39755^{*}$ \\
\hline D(KURS(1)) & 0.014663 & 1.14134 \\
\hline D(KURS(2)) & -0.014256 & -1.12383 \\
\hline $\mathrm{D}(\mathrm{IPI}(-1))$ & -0.958144 & $-1.46351 *$ \\
\hline $\mathrm{D}(\mathrm{IPI}(-2))$ & -0.876448 & $-1.60854^{*}$ \\
\hline $\mathrm{D}(\mathrm{OP}(-1))$ & -4.190149 & -1.07686 \\
\hline $\mathrm{D}(\mathrm{OP}(-2))$ & -14.12243 & $-3.75486 * * *$ \\
\hline D(DJIMf1)) & 503.3073 & $3.31417 * * *$ \\
\hline D(DJIMf(2)) & -26.87077 & -0.20681 \\
\hline D(MHS $(-1))$ & -0.024407 & $-2.32993 * *$ \\
\hline $\mathrm{D}(\mathrm{MHS}(2))$ & -0.020216 & $-1.88542 * *$ \\
\hline $\mathrm{C}$ & $-0,850012$ & -0.28501 \\
\hline
\end{tabular}

*significant at 10\%, ** significant at 5\%, ***significant at $1 \%$

Table 7 shows the long- and short-term VECM estimation results, with the error correction value shown on the co-integration line. Eq of -0.654982 implies that the speed in adjusting towards the long-term trend is $0.65 \%$, with two lags. Furthermore, the significant error correction value indicates an acclimation from the short to the long term. The equation of this research model is: 
$\mathrm{D}(\mathrm{JII})=-0.654982 *(\mathrm{JII}(-1)+980.93784 * \mathrm{DJIM}(-1)-0.038573 * \mathrm{MHS}(-1)-3.61014 * \mathrm{IP}(-1)-$ $8.85499 * \mathrm{OP}(-1)+8.22737 * \operatorname{INF}(-1)+19.81249 * \operatorname{BIRATE}(-1)+0.01604 * \mathrm{KURS}(-1)-$ $0.31640 * @$ TREND(15M06) - 1036.3573) + 0.46125*D(JII(-1)) + 0.48572*D(JII(-2)) + $503.30732 * \mathrm{D}(\mathrm{DJIM}(-1))-26.87077 * \mathrm{D}(\mathrm{DJIM}(-2))-0.02441 * \mathrm{D}(\mathrm{MHS}(-1))-$ $0.02022 * \mathrm{D}(\mathrm{MHS}(-2))-0.95815 * \mathrm{D}(\mathrm{IP}(-1))-0.87645 * \mathrm{D}(\mathrm{IP}(-2))-4.19015 * \mathrm{D}(\mathrm{OP}(-1))-$ $14.12243 * \mathrm{D}(\mathrm{OP}(-2))-0.24989 * \mathrm{D}(\mathrm{INF}(-1))-6.63408 * \mathrm{D}(\mathrm{INF}(-2))-2.57292 * \mathrm{D}(\mathrm{BIRATE}(-1))$ $+15.61007 * \mathrm{D}(\mathrm{BIRATE}(-2))+0.014672 * \mathrm{D}(\operatorname{KURS}(-1))-0.014256 * \mathrm{D}(\mathrm{KURS}(-2))-0.85002$

JII affects itself significantly and positively in the short-term at the first and second lags. This confirms the random walk theory and the weak form of the efficient market hypothesis proposed by Fama (1970), which stated that current stock prices represent previous stock prices. The first lag with a coefficient of 0.461240 means that every increase of 1 rupiah JII in the previous month raises the price by 0.46 rupiah. Similarly, the second lag with a coefficient of 0.485712 means that every 1 rupiah price increase in the previous two months raises the current price by 0.48 rupiah. This is in line with Wulandari et al. (2019) that share prices affect themselves.

Inflation significantly and positively affects JII in the long run. The coefficient of 8.227363 indicates that every $1 \%$ change in inflation increases JII by IDR 8.2. This supports Simbolon and Purwanto (2018) that inflation increases stock prices. Light inflation stimulates economic growth (Sutawijaya \& Zulfahmi, 2012) because people increase their savings and investment, triggering a rise in stock prices.

$\mathrm{BI}$ rate significantly and positively affects $\mathrm{JII}$ in the long-term at $1 \%$ and short-term at $10 \%$. Therefore, a $1 \%$ increase in the BI rate raises the JII by IDR by 19.8 in the long term. Also, a $1 \%$ increase in BI rate in the previous two months raises JII of IDR by 15.61 in the short term. These results contradict most previous studies, which found that interest rates negatively affect stock prices. For instance, Beik and Fatmawati (2014) stated that Islamic stock indices are not affected by interest rates. However, this study supports Rigobon and Sack (2004) and Nurlina (2017), which stated that inflation positively affects stock prices.

IPI negatively affects JII in the long-term at $1 \%$ and in the short-term at $10 \%$. In the long term, a $1 \%$ increase in IPI decreases JII by IDR 3.6. Similarly, a 1\% increase in IPI reduces JII by IDR 0.95 and IDR 0.87 in the previous one and two months in the short term. However, these results differ from most previous studies that found that IPI positively affects stock prices. For instance, Mankiw (2006) stated that an increase in IPI raises company profits and stock prices. However, this research is in line with Chun et al. (2015) and Ash-Shiddiqy (2019), which stated that IPI negatively affects stock prices.

The world oil price negatively and significantly affects JII in the long-and short-term at $1 \%$. The increase in world oil prices is associated with higher production costs and low profits (Mankiw, 2006). This could reduce share prices because stocks are considered less profitable. 
Therefore, an increase in world oil prices by 1USD could reduce JII by IDR 8.8 in the long term and by IDR 14.1 in the short term. These findings support Kelikume and Muritala (2019) and Alfuadi (2019), which showed that stock prices are negatively affected by world oil prices.

Dow Jones Islamic Market Malaysia Titan 25 positively and significantly impacts stock prices in the long-and short-term. Also, the global stock index responds sensitively to the local stock index. Jayanti, Darminto and Sudjana (2014) stated that there is a contagion positive or negative effect between state conditions and other countries. DJIM raised JII by IDR 980.9 at each increment per RM. 1 in the long term. Similarly, in the short term, every RM. 1 increase in the previous month raised JII by IDR 503.3. These results supportKurniawan et al. (2019) and Setiawan (2019), which showed that the global stock index negatively affects stock prices.

Malaysia Hijrah Shariah (MHS) negatively and strongly correlates with stock prices in the long-and short-term. The contagion effect could occur in an integrated country (Jayanti et al., 2014), such as between Indonesia and Malaysia. Therefore, the economic conditions in one country would affect the other. Similarly, the stock market produces a contagion effect. JII and MHS are Islamic stock indices in Indonesia and Malaysia. Therefore, changes in stock price volatility would affect both countries simultaneously. The results showed a negative sensitivity from MHS, whose increase by $1 \%$ would reduce JII by IDR 0.03 in the long term. In the short term, JII decreases by IDR 0.024 and IDR 0.020 when MHS increases $1 \%$ in the previous one and two months, respectively.

\section{Impulse Respons Function (IRF)}

Impuls Respons Function (IRF) is used to determine the endogenous variables' response to shocks, innovations, or policies from exogenous variables. A curve above point 0 means that the endogenous variable responds positively to the shock from the exogenous variable and otherwise. The results are as follow:

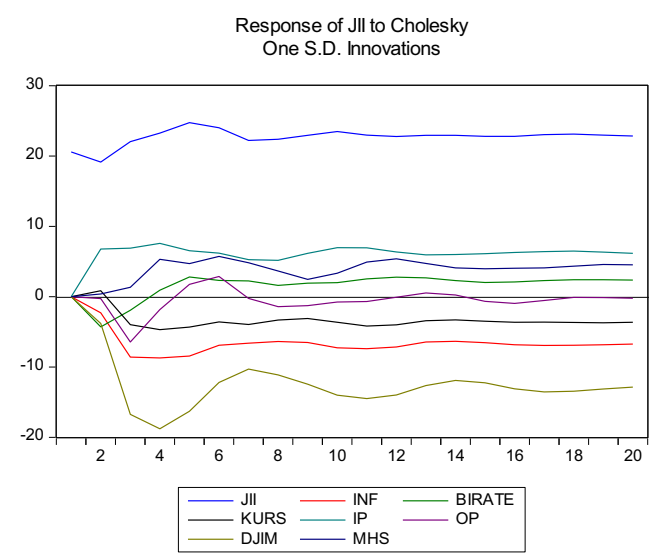

Figure 3. Impulse Respons Function 
Figure 3 shows that JII responded to itself positively and stabilized in period 20. The response is fastest in the initial period, with a standard deviation of $20.58 \%$. This shows that the greatest volatility of the JII index is influenced by itself. Furthermore, past prices have strongly influenced JII volatility.

JII responded negatively to DJIM and stabilized in period 16. The response is negative in the first and second periods, with a standard deviation of $-3.81 \%$. Also, JII responded to itself and later strongly to DJIM in the second composition. DJIM significantly influenced the volatility of JII volatility.

JII responded positively to MHS in period two before stabilizing. Its influence starts to increase in the third and peaks in the sixth period. Moreover, MHS influenced the JII volatility, though with a relatively smaller range than JII and DJIM.

JII responded positively to IPI and stabilized in period 5. It responded to IPI in the second period with a standard deviation of $6.76 \%$. Also, IPI, which shows a country's industrial production ability, influenced the JII volatility. The increase in IPI implies a good economy and boosts investor confidence.

JII responded negatively to oil prices and stabilized in period 7 . World oil prices are the longest-responded variable by the JII index in the initial period with a standard deviation of only $-0.28 \%$. They insignificantly influenced the JII volatility because they do not directly affect prices. However, an increase in oil prices raises the production cost and decreases profits, providing negative information to investors.

JII responded negatively to inflation, and the effect stabilized in period 7. It had a standard deviation of $-2.31 \%$ in the second period. Inflation is a measure of a country's economy and reduces investor confidence when uncontrolled. Therefore, the increase in inflation is responded to negatively by the JII index.

JII responded negatively to the interest rate from the second to third periods. However, the response became positive after the fourth period and stabilized in period 11 . The increase in interest rates made investors switch to deposits with substantive benefits. Therefore, the interest rates should not significantly influence Islamic stocks. However, the field conditions between Islamic and conventional stocks respond to interest rates with the same tendency.

JII initially responded positively to the exchange rate with a standard deviation of $0.84 \%$ before becoming negative and stabilizing. This study used the exchange rate per 1 USD. Therefore, every increase in the rupiah's value per 1 USD means that the rupiah has depreciated. Currency appreciation implies a strengthening economy, boosting investor confidence. 
The JII responses to shocks or impulses from endogenous variables show that the efficient market hypothesis theory occurred in Indonesia. This study shows that Indonesia could be categorized as semi-strong. According to Fama (1970) the hypothesis of the efficient market is a half-strong form. This means that it is influenced by past stock prices and fundamental macroeconomic information. The response of JII to shocks from Malaysian Islamic stock indices shows that contagion theory occurred in Indonesian Islamic stock indices.

Local and global economic conditions are uncertain, as stated in Al-Qur'an surah Luqman:34 that "no one will know (with certainty) He will do tomorrow". Therefore, an investor must carefully compound investment to avoid losses. Based on Al-Qur'an surah AlHasyr:18, "Islam recommends moslem investing in preparing for the future". Similarly, companies are uncertain about macroeconomics conditions and always improve performance to maintain the stock price stability. Therefore, as a policymaker, the government must ensure economic stability to maintain investor confidence.

\section{CONCLUSION}

Inflation has a significant long-term and no short-term effect. BI rate has a significant effect in long-and short-term, while the exchange rate has no impact. Furthermore, Industrial Production Index, oil price, Dow Jones Islamic Market Malaysia, and Malaysia Hijrah Shariah have significant effects in long-and short-term. JII responded to the impulses from all exogenous variables. Therefore, these results confirmed the theory of the semi-strong form of an efficient market hypothesis.

This research implies that the JII index is very sensitive to economic changes. Investors should consider economic conditions and the stock market before taking any investment steps. Also, this study showed that interest rate affects JII. Therefore, an effective formulation is needed to minimize interest rates on JII or other Indonesian Islamic Stocks. Stakeholders are more careful in making policies, which have a domino economic effect. This study had a limited range of research periods. Therefore, further studies should extend the research period and identify the emiten to obtain more comprehensive results.

\section{BIBLIOGRAPHY}

Agriyanto, R. (2015). Redefining Objective of Islamic Banking; Stakeholders Perspective in Indonesia. Economica: Jurnal Ekonomi Islam, 6(2), 77-90. https://doi.org/https: //doi.org/10.21580/economica.2015.6.2.795. 
Akbar, R. A., Rusgiyono, A., \& Tarno. (2016). Analisis Integrasi Pasar Bawang Merah Menggunakan Metode Vector Error Correction Model (VECM) (Studi Kasus: Harga Bawang Merah di Provinsi Jawa Tengah). Jurnal Gaussian, 5(4), 811-820. https://doi.org/10.14710/j.gauss.v5i4.17110.

Al-Majali, A. A., \& Al-Assaf, G. I. (2014). Long-Run and Short-Run Relationship between Stock Market Index and Main Macroeconomic Variables Performance in Jordan. European Scientific Journal, 10(10), 156-171.

Alfuadi, M. U. A. (2019). Analisis Dampak Harga Emas Dunia, Harga Minyak Dunia, Indeks Harga Konsumen (IHK), dan BI Rate terhadap Jakarta Islamic Index. Journal of Enterprise and Development, 1(2), 7-20.

Andriana, D. (2015). Pengaruh Nilai Tukar terhadap Harga Saham Setelah Initial Public Offering (IPO). Jurnal Riset Akuntansi dan Keuangan, 3(3), 761-767. https://doi.org/10.17509/jrak.v3i3.6619.

Antonio, M. S., Hafidhoh, \& Fauzi, H. (2013). Volatilitas Pasar Modal Syariah dan Indikator Makro Ekonomi: Studi Banding Malaysia dan Indonesia. Jurnal Liquidity: Jurnal Riset Akuntansi dan Manajemen, 2(1), 1-12.https://doi.org/10.32546/lq.v2i1.124.

Ardana, Y. (2016). Pengaruh Variabel Makroekonomi terhadap Indeks Saham Syariah di Indonesia: Model ECM. Esensi: Jurnal Bisnis dan Manajemen, 6(1), 17-28. https://doi.org/10.15408/ess.v6i1.3118.

Ash-Shiddiqy, M. (2019). Pengaruh Indeks Produksi Industri (IPI), Sertifikat Bank Indonesia Syariah (SBIS), Inflasi dan Nilai Tukar terhadap Indeks Saham Syariah Indonesia (Periode 2012-2018). Panangkaran: Jurnal Penelitian Agama dan Masyarakat, 3(1), 39-50. https://doi.org/DOI: 10.14421/panangkaran.2019.0301-03.

Basuki, A. T., \& Prawoto, N. (2017). Analisis Regresi dalam Penelitian Ekonomi dan Bisnis (1sted.). Depok: PT. Raja Grafindo Persada.

Beik, I. S., \& Fatmawati, S. W. (2014). Pengaruh Indeks Harga Saham Syariah Internasional dan Variabel Makro Ekonomi terhadap Jakarta Islamic Index. Al-Iqtishad, 6(2), 155-178. https://doi.org/10.15408/aiq.v6i2.1228.

Blanchard, O. J. (2006). Macroeconomic (4th ed.). New Jersey: Pearson Prentice Hall.

Chun, O. P., Arsad, Z., \& Huen, T. B. (2015). Dynamic Relationship between Stock Prices and Economic Variables in Malaysia. AIP Conference Proceeding 1605, 822-827. https://doi.org/10.1063/1.4887696.

Enders, W. (2004). Applied Econometric Time Series (2nd ed.). New Jersey: John Wiley \& Sons Inc. 
Fama, E. F. (1970). Efficient Capital Markets: A Review of Theory and Empirical Work. The Journal of Finance, 25(2), 383-417. https://doi.org/10.2307/2325486.

Faraga, F., Chabachib, M., \& Muharam, H. (2012). Analisis Pengaruh Harga Minyak dan Harga Emas terhadap Hubungan Timbal-Balik Kurs dan Indek Harga Saham Gabungan (IHSG) di Bursa Efek Indonesia (BEI) 2000-2013. Jurnal Bisnis Strategi, 21(1), 72-94. https://doi.org/10.14710/jbs.21.1.72-94.

Febrina, R. S., Sumiati, \& Ratnawati, K. (2018). Pengaruh Variabel Makroekonomi dan Harga Saham Asing terhadap Indeks Harga Saham Gabungan. Jurnal Bisnis dan Manajemen, 5(1), 118-126. https://doi.org/10.26905/jbm.v5i1.2321.

Fitriany. (2012). Analisa Pengaruh Krisis Global Financial terhadap Jakarta Islamic Index (JII) dan Indeks Harga Saham gabungan (ISHG). Jurnal Ekonomi dan Keuangan Islam, 2(1), 1-12.

Gujarati, D. N., \& Porter, D. C. (2012). Dasar-Dasar Ekonometrika Edisi 5-Buku 2 (5th ed.). Jakarta: Salemba Empat.

Habiburrahman. (2015). Analisis Pengaruh Nilai Tukar Rupiah dan Inflasi terhadap Indeks Harga Saham Sektor Properti di Bursa Efek Indonesia. Jurnal Manajemen dan Bisnis, 5(2), 112-129.

Harsono, A. R., \& Worokinasih, S. (2018). Pengaruh Inflasi, Suku Bunga, dan Nilai Tukar Rupiah terhadap Indeks Harga Saham Gabungan (Studi pada Bursa Efek Indonesia Periode 2013-2017). Jurnal Administrasi Bisnis, 60(2), 102-110.

Hartono, J. (2010). Teori Portofolio dan Analisis Investasi (Edisi Sepuluh). Yogyakarta: BPFE.

Hussin, M. Y. M., Muhammad, F., Abu, M. F., \& Awang, S. A. (2012). Macroeconomic Variables and Malaysian Islamic Stock Market: A Time Series Analysis. Journal of Bussiness Studies Quarterly, 3(4), 1-13.

Jayanti, Y., Darminto, \& Sudjana, N. (2014). Pengaruh Tingkat Inflasi, Tingkat Suku Bunga SBI, Nilai Tukar Rupiah, Index Dow Jones, dan Indeks KLSE terhadap Indeks Harga Saham Gabungan (IHSG): Studi pada Bursa Efek Indonesia Periode Januari 2010 Desember 2013. Jurnal Administrasi Bisnis, 11(1), 1-10.

Kelikume, I., \& Muritala, O. (2019). The Impact of Changes in Oil Price on Stock Market : Evidence from Africa. International Journal of Management, Economics and Social Sciences, 8(3), 169-194.https://doi.org/http://dx.doi.org/10.32327/IJMESS/8.3. 2019.11 .

Kurniawan, A., Alia, F., \& Apriyani, M. (2019). Pengaruh Dow Jones Islamic World Malaysia Index dan Dow Jones Islamic Market Japan terhadap Indeks Saham Syariah Indonesia (Periode Januari 2013-Desember 2017). Finansia: Jurnal Akuntansi dan Perbankan Syariah, 2(1), 93-106. https://doi.org/10.32332/finansia.v2i01.1543. 
Lubis, I. (2017). Pengaruh Makro Ekonomi terhadap Pasar Saham Liquid di Indonesia. Jurnal Mandiri: Ilmu Pengetahuan, Seni, dan Teknologi, 1(1), 57-67.https://doi.org/10. 33753/mandiri.v1i1.9.

Mankiw, N. G. (2006). Makro Ekonomi. Jakarta: Erlangga.

Nurlina. (2017). Pengaruh Nilai Tukar dan Suku Bunga terhadap Harga Saham PT. Bank Rakyat Indonesia Tbk. Jurnal Samudra Ekonomika, 1(1), 33-41.https://doi.org/10. 1234/jse.v1i1.64.

Pantas, P. E. (2017). Guncangan Variabel Makroekonomi terhadap Jakarta Islamic Index (JII). Cakrawala: Jurnal Studi Islam, 12(1), 28-43. https://doi.org/10.31603/cakrawala. v12i1.1662.

Pratama, Y. C. (2012). Analisis Responsivitas Bursa Syariah oleh Variabel Makro Ekonomi. AlIqtishad: Jurnal Ilmu Ekonomi Syariah, 4(2), 259-270. 10.15408/aiq.v4i2.2548.

Putri, A. (2018). Analisis Pengaruh Variabel Makroekonomi terhadap Perkembangan Indeks Saham Syariah Indonesia (ISSI). Skripsi. Bogor: Institut Pertanian Bogor.

Rigobon, R., \& Sack, B. (2004). The Impact of Monetary Policy on Asset Prices. Journal of Monetary Economics, 51(8), 1553-1575.https://doi.org/doi:10.1016/j.jmoneco. 2004.02.004.

Rozalinda. (2015). Ekonomi Islam: Teori dan Aplikasinya pada Aktifitas Ekonomi. Depok: PT. Rajawali Press.

Rusbariand, S. P., Masodah., Riskayanto., \& Herawati, S. (2012). Analisis Pengaruh Tingkat Inflasi, Harga Minyak Dunia, Harga Emas Dunia, dan Kurs Rupiah terhadap Pergerakan Jakarta Islamic Index di Bursa Efek Indonesia. Prosiding Seminar Nasional Forum Bisnis dan Keuangan I, 724-740.

Sakti, M. R. P., \& Harun, M. Y. (2013). Relationship between Islamic Stock Prices and Macroeconomic Variables: Evidence from Jakarta Stock Exchange Islamic Index. Global Review of Islamic Economics and Business, 1(1), 71-84. https://doi.org/10. 14421/grieb.2013.011-06.

Setiawan, M. A. (2019). Analisis Pengaruh Dow Jones Islamic Market Asia/Pacific Ex-Japan (DJIP2), Dow Jones Arabia Titans 50 (DJARB50), Harga Emas Dunia, dan Nilai Kurs Terhadap JII Tahun 2016-2018. Li Falah: Journal of Islamic Economics and Business Studies, 4(1), 64-78. https://doi.org/DOI: 10.31332/lifalah.v4i1.1343.

Shanmugam, B., \& Zahari, Z. R. (2009). A Primer on Islamic Finance. Research Foundation of CFAInstitute. https://doi.org/http://www.tandfonline.com/doi/abs/10.2753/REE1540 $-496 \times 500211$. 
Shofiyullah, N. F. (2014). Komparasi Jakarta Islamic Index dan FTSE Bursa Malaysia Hijrah Shariah Index. Jurnal Bisnis dan Manajemen, 14(2), 19-34. https://doi.org/10.20961 /jbm.v14i2.4122.

Simbolon, L., \& Purwanto. (2018). The Influence of Macroeconomic Factors on Stock Price: The Case of Real Estate and Property Companies. Kensinger, J.W. (Ed.) Global Tensions in Financial Markets (Research in Finance, Vol. 34), Emerald Publishing Limited, Bingley, 19-39. https://doi.org/10.1108/S0196-382120170000034010.

Sutawijaya, A., \& Zulfahmi. (2012). Pengaruh Faktor-Faktor Ekonomi Terhadap Inflasi di Indonesia. Jurnal Organisasi dan Manajemen, 8(2), 85-101.

Widarjono, A. (2005). Ekonometrika: Teori dan Aplikasi untuk Ekonomi dan Bisnis. Yogyakarta: Ekonisia Fakultas Ekonomi Universitas Islam Indonesia.

Wulandari, W., Herlina, D., \& Chendrawan, T. S. (2019). Dampak Kurs, SBI, Inflasi dan Indeks NIKKEI 225 terhadap Indeks Harga Saham Gabungan di Bursa Efek Indonesia. JEQu, 9(2), 131-155.http://dx.doi.org/10.35448/jequ.v2i2.7164. 